\title{
Martensitic Transformation and Magnetic Properties of Ni-Co-Mn-In-Gd Ferromagnetic Shape Memory Alloys
}

\author{
Kaifeng Li, Li Gao* and Yongcheng Liang \\ College of Engineering Science and Technology, Shanghai Ocean University, Shanghai 201306, China
}

\begin{abstract}
The effect of rare earth Gd on the microstructure, martensitic transformation and magnetic properties of ${ }^{2}{ }_{45} \mathrm{Co}_{5} \mathrm{Mn}_{35} \mathrm{In}_{15-\mathrm{x}} \mathrm{Gd}_{\mathrm{x}}(0 \leq \mathrm{x} \leq$ 1.6) alloys is investigated. The addition of $\mathrm{Gd}$ results in a change in the microstructure. With the increase of Gd content, the grain size is clearly reduced and the volume fraction of the second phase increases gradually. And then the second phase along the grain boundaries grows and connects to each other. Some disperse in the grains. One-step thermoelastic martensitic transformation is observed in $\mathrm{Ni}_{45} \mathrm{Co}_{5} \mathrm{Mn}_{35} \mathrm{In}_{15-\mathrm{x}} \mathrm{Gd}_{\mathrm{x}}$ alloys. When the Gd content reaches 0.8 (at\%), the martensite transformation temperature decreases first, and then rises with the increase of Gd content. The near-room-temperature magnetocaloric effect (MCE) in polycrystalline $\mathrm{Ni}_{45} \mathrm{Co}_{5} \mathrm{Mn}_{35} \mathrm{In}_{14.2} \mathrm{Gd}_{0.8}$ alloys is observed. The magnetic-field-induced inverse phase transformation from martensite to austenite phase is confirmed. The inverse magnetic entropy change $\left(\Delta \mathrm{S}_{\mathrm{M}}\right)$ reaches $17.78 \mathrm{~J} / \mathrm{kg} \mathrm{K}$ for $\mathrm{Ni}_{45} \mathrm{Co}_{5} \mathrm{Mn}_{35} \mathrm{In}_{14.2} \mathrm{Gd}_{0.8}$ alloy at $277 \mathrm{~K}$ and its $\mathrm{R}_{\mathrm{c}}$ is about $356 \mathrm{~J} \mathrm{Kg}^{-1}$ at an applied field of 5 T. [doi:10.2320/matertrans.M2017311]
\end{abstract}

(Received October 18, 2017; Accepted November 20, 2017; Published January 25, 2018)

Keywords: ferromagnetic shape memory alloy, rare earth element, martensitic transformation, second phases, magnetocaloric effects

\section{Introduction}

The Ni-Mn based Heusler alloys with martensitic transition have attracted a lot of interest in recent years due to potential applications ${ }^{1-6)}$. Ni-Mn-In Heusler alloys exhibit unique shape recovery behaviors due to the magnetic-field-induced phase transformation and perfect shape memory effect (SME) of about $7 \%$ with almost $100 \%$ of shape recovery rate ${ }^{2)}$. Magnetocaloric effect (MCE) is drawing great attention because of its potential application in magnetic refrigeration. Compared with a traditional gas refrigeration method, the magnetic refrigeration shows advantages such as compactness, high efficiency and environmental friendship ${ }^{7)}$. To achieve low cost production and high MCE at room temperature, Ni-Mn based Heusler alloys have also been attracting considerable attention ${ }^{8}$, including conventional $\mathrm{MCE}$ in $\mathrm{Ni}-\mathrm{Mn}-\mathrm{Ga}^{9}$ ) and inverse $\mathrm{MCE}$ in $\mathrm{Ni}-$ Mn-In, Ni-Mn-Sn, and Ni-Co-Mn-In ${ }^{10)}$. Gd has the highest Curie temperature in the Rare earth elements. The characteristic of $\mathrm{Gd}$ with $4 \mathrm{f}$ electronic layer may improve MCE of $\mathrm{Ni}-\mathrm{Co}-\mathrm{Mn}$-In-Gd alloys. However, little information about heavy rare earth Gd-doped Ni-Co-Mn-In alloys is available up to now. Therefore, it is of much importance for further investigation on such compositional polycrystalline $\mathrm{Ni}-\mathrm{Co}-$ Mn-In-Gd alloys. The aim of the present paper is to investigate the influence of $\mathrm{Gd}$ content on the structural and magnetic transition temperatures in $\mathrm{Ni}_{45} \mathrm{Co}_{5} \mathrm{Mn}_{35} \mathrm{In}_{15-\mathrm{x}} \mathrm{Gd}_{\mathrm{x}}$ $(0 \leq x \leq 1.6)$ alloys.

\section{Material and Method}

$\mathrm{Ni}_{45} \mathrm{Co}_{5} \mathrm{Mn}_{35} \mathrm{In}_{15-\mathrm{x}} \mathrm{Gd}_{\mathrm{x}}(0 \leq \mathrm{x} \leq 1.6)$ polycrystalline were prepared by arc melting elemental mixture of $\mathrm{Ni}(99.95 \%)$, Co (99.95\%), Mn (99.92\%), In (99.95\%), and Gd (99.95\%) under argon atmosphere, then cast into rods with $10 \mathrm{~mm}$ in diameter. The rods were homogenized at $1173 \mathrm{~K}$ for $12 \mathrm{~h}$ in a sealed quartz tube, and then quenched in cold water. The

*Corresponding author, E-mail: 1gao@shou.edu.cn microstructures of alloys were examined use a Hitachi S-4800 scanning electron microscope (SEM) equipped with an energy dispersive X-ray spectroscopy (EDS) analysis system. The phase transformation temperatures of this alloy were measured by differential scanning calorimetry (DSC, PerkinElmer). Magnetic measurements were taken by physical properties measurement system (PPMS, Quantum Design) in an applied field up to $5 \mathrm{~T}$.

\section{Results and Discussion}

Figure 1 shows the backscattered electron images of $\mathrm{Ni}_{45} \mathrm{Co}_{5} \mathrm{Mn}_{35} \mathrm{In}_{15-\mathrm{x}} \mathrm{Gd}_{\mathrm{x}}(\mathrm{x}=0,0.8,1,1.2,1.4,1.6)$ alloys (uncorroded). Obviously, the addition of Gd significantly changes the microstructure of $\mathrm{Ni}_{45} \mathrm{Co}_{5} \mathrm{Mn}_{35} \mathrm{In}_{15}$. As shown in Fig. 1, the $\mathrm{Ni}_{45} \mathrm{Co}_{5} \mathrm{Mn}_{35} \mathrm{In}_{15}$ alloy is monophase, while the microstructure of the alloys containing Gd consists of the matrix (black area) and the second phase (white area). When the content of Gd is 0.8 at $\%$, a small amount of the second phase disperses in the grains and some distribute along the grain boundaries. When $\mathrm{x}=1$, more the second phase disperses in the grains and gathers along the grain boundaries compared with $\mathrm{Ni}_{45} \mathrm{Co}_{5} \mathrm{Mn}_{35} \mathrm{In}_{14.2} \mathrm{Gd}_{0.8}$. As the content of $\mathrm{Gd}$ increases, the second phase interconnects gradually and tends to segregate at the grain boundaries. It also can be seen that the volume fraction of the second phase rises gradually with the increase of Gd content. When $x=1.6$, the second phase along the grain boundaries is fully interconnected and the grain size is the smallest compared to others, which indicates that the grain reduce with the increase of $\mathrm{Gd}$ content. The grain size of $\mathrm{Ni}_{45} \mathrm{Co}_{5} \mathrm{Mn}_{35} \mathrm{In}_{14.2} \mathrm{Gd}_{0.8}$ alloy is almost twice bigger than $\mathrm{Ni}_{45} \mathrm{Co}_{5} \mathrm{Mn}_{35} \mathrm{In}_{13.4} \mathrm{Gd}_{1.6}$. Compared with the microstructure in $\mathrm{Ni}-\mathrm{Mn}-\mathrm{Ga}$ alloys including rare earth element ${ }^{11,12)}$, the $\mathrm{Ni}_{45} \mathrm{Co}_{5} \mathrm{Mn}_{35} \mathrm{In}_{15-\mathrm{x}} \mathrm{Gd}_{\mathrm{x}}(0 \leq \mathrm{x} \leq 1.6)$ alloys indicate a similar change of the microstruture except for the existence of more granular second phase inside the grains.

The Table 1 shows the EDS results of $\mathrm{Ni}_{45} \mathrm{Co}_{5} \mathrm{Mn}_{35} \mathrm{In}_{15-\mathrm{x}} \mathrm{Gd}_{\mathrm{x}}$. It can be see that there is no Gd detected in the matrix. This means that the solubility of Gd in 

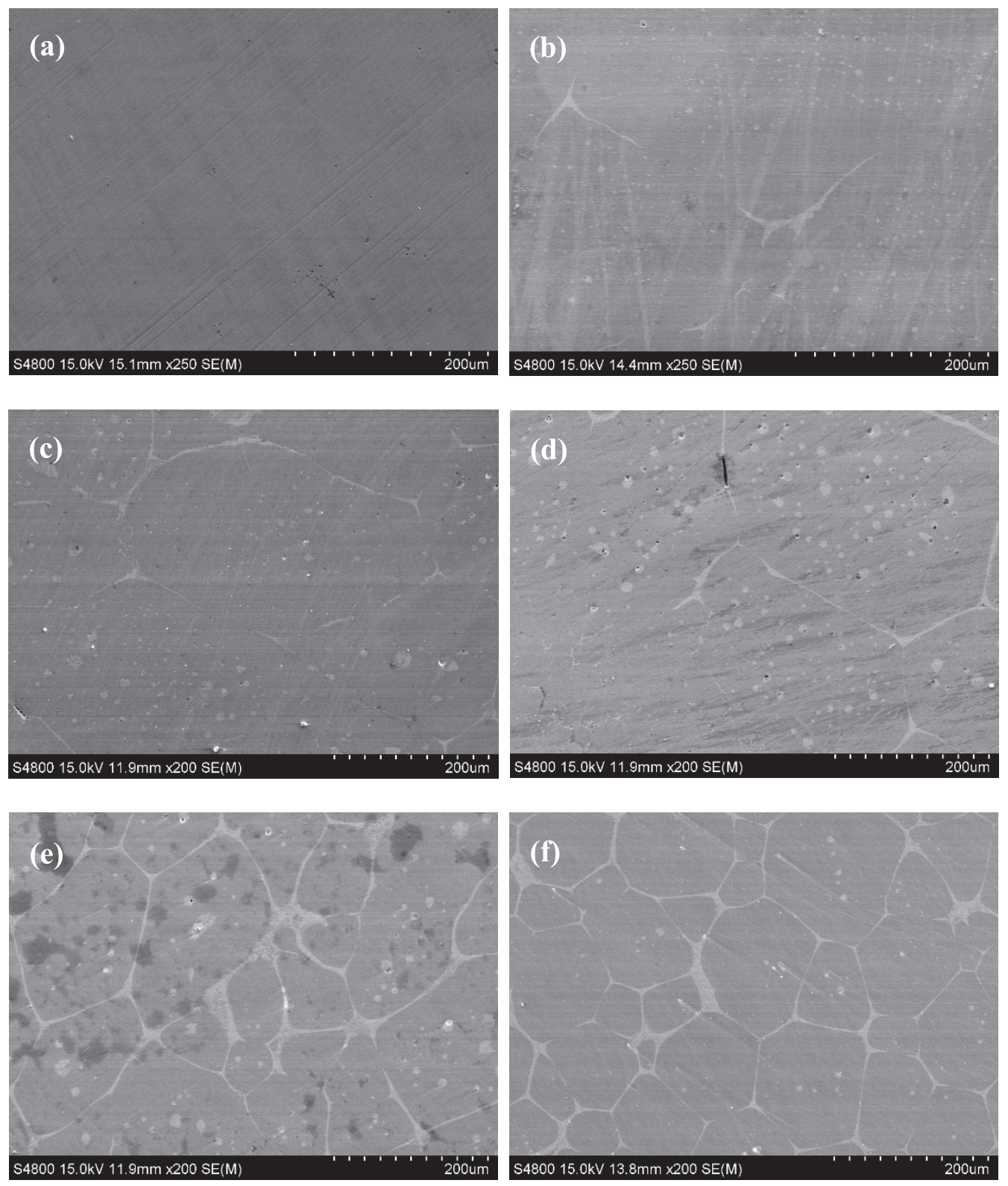

Fig. 1 Blackscattering electron images of $\mathrm{Ni}_{45} \mathrm{Co}_{5} \mathrm{Mn}_{35} \operatorname{In}_{15-\mathrm{x}} \mathrm{Gd}_{\mathrm{x}}$ alloys: (a) $\mathrm{x}=0$; (b) $\mathrm{x}=0.8$; (c) $\mathrm{x}=1 ;$ (d) $\mathrm{x}=1.2$; (e) $\mathrm{x}=1.4$; (f) $\mathrm{x}=1.6$.

Table 1 The EDS results of $\mathrm{Ni}_{45} \mathrm{Co}_{5} \mathrm{Mn}_{35} \mathrm{In}_{15-\mathrm{x}} \mathrm{Gd}_{\mathrm{x}}(\mathrm{x}=0,0.8,1.0,1.2$, $1.4,1.6)$ alloys.

\begin{tabular}{|c|c|c|c|c|c|c|}
\hline Phase & $\begin{array}{c}\text { Rare earth } \\
\text { content } x\end{array}$ & $\begin{array}{c}\mathrm{Ni} \\
(\mathrm{at} \%)\end{array}$ & $\begin{array}{c}\mathrm{Co} \\
\text { (at } \%)\end{array}$ & $\begin{array}{c}\mathrm{Mn} \\
(\mathrm{at} \%)\end{array}$ & $\begin{array}{c}\text { In } \\
(\mathrm{at} \%)\end{array}$ & $\begin{array}{r}\mathrm{Gd} \\
(\mathrm{at} \%)\end{array}$ \\
\hline \multirow{6}{*}{ Matrix } & 0 & 45.1 & 5.1 & 35.5 & 14.3 & - \\
\hline & 0.8 & 45.8 & 5.0 & 35.9 & 13.3 & - \\
\hline & 1 & 44.8 & 5.2 & 37.8 & 12.2 & - \\
\hline & 1.2 & 46.6 & 4.8 & 36.7 & 11.8 & - \\
\hline & 1.4 & 47.4 & 5.1 & 37.2 & 10.3 & - \\
\hline & 1.6 & 45.6 & 5.8 & 38.8 & 9.8 & - \\
\hline \multirow{5}{*}{ The second phase } & 0.8 & 33.2 & 3.2 & 12.4 & 38.3 & 12.9 \\
\hline & 1 & 40.3 & 4.9 & 11.9 & 28.3 & 14.6 \\
\hline & 1.2 & 36.4 & 4.4 & 14.1 & 31.8 & 13.3 \\
\hline & 1.4 & 39.4 & 4.1 & 12.2 & 32.6 & 14.7 \\
\hline & 1.6 & 36.2 & 3.9 & 12.8 & 33.7 & 13.7 \\
\hline
\end{tabular}

the matrix is very low. In the matrix, with the increase of $\mathrm{Gd}$, the content of $\mathrm{Ni}$ and Co keep almost unchanged and Mn content increases, whereas In content decreases. Compared with the composition of the matrix, the second phase has a larger concentration of Gd and In, and a smaller concentration of $\mathrm{Mn}$ and $\mathrm{Ni}$, while the Co content remains almost unchanged. As shown in the Table 1, Gd content is almost constant in the second phase, which indicates insolvable Gd element form the Gd-rich phase.

X-ray diffraction patterns of $\mathrm{Ni}_{45} \mathrm{Co}_{5} \mathrm{Mn}_{35} \mathrm{In}_{15-\mathrm{x}} \mathrm{Gd}_{\mathrm{x}}(\mathrm{x}=$ $0,0.8,1,1.2,1.4,1.6)$ alloys at room temperature are shown in the revised manuscript. Figure 2 shows the X-ray diffraction patterns of $\mathrm{Ni}_{45} \mathrm{Co}_{5} \mathrm{Mn}_{35} \mathrm{In}_{15-\mathrm{x}} \mathrm{Gd}_{\mathrm{x}}(\mathrm{x}=0,0.8,1,1.2$, 1.4 , 1.6) alloys at room temperature. For the $\mathrm{Ni}_{45} \mathrm{Co}_{5} \mathrm{Mn}_{35} \mathrm{In}_{15}$ and $\mathrm{Ni}_{45} \mathrm{Co}_{5} \mathrm{Mn}_{35} \mathrm{In}_{14.2} \mathrm{Gd}_{0.8}$ alloys, the $\mathrm{X}$-ray diffraction patterns are all indexed to coexistence of $10 \mathrm{M}$ modulated martensite structure and $\mathrm{L} 2{ }_{1}$ cubic austenite structure. It is consistent with the DSC results. Whereas, 


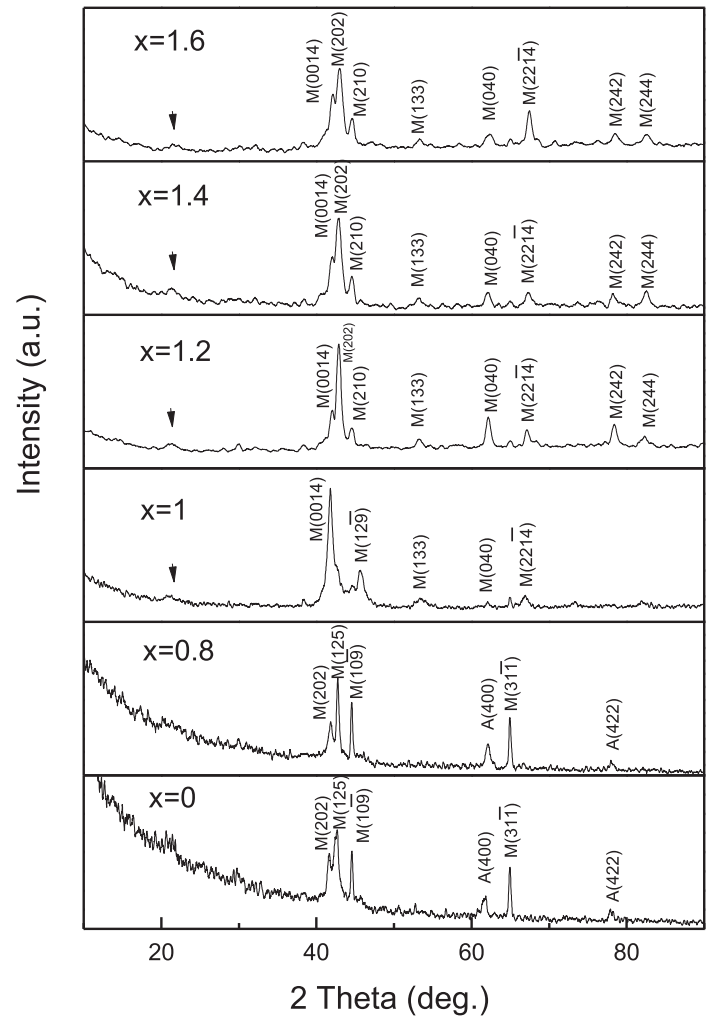

Fig. 2 X-ray diffraction patterns of $\mathrm{Ni}_{45} \mathrm{Co}_{5} \mathrm{Mn}_{35} \mathrm{In}_{15-\mathrm{x}} \mathrm{Gd}_{\mathrm{x}}$ alloys at room temperature: (a) $\mathrm{x}=0$; (b) $\mathrm{x}=0.8$; (c) $\mathrm{x}=1$; (d) $\mathrm{x}=1.2$; (e) $\mathrm{x}=1.4$; (f) $\mathrm{x}=1.6$.

when the content of $\mathrm{Gd}$ is between 1 at $\%$ and 1.6 at $\%, 14 \mathrm{M}$ structure is observed and the main reflection is indexed on a monoclinic structure. The lattice parameters and crystal phase for $\mathrm{Ni}_{45} \mathrm{Co}_{5} \mathrm{Mn}_{35} \mathrm{In}_{15-\mathrm{x}} \mathrm{Gd}_{\mathrm{x}}(\mathrm{x}=0,0.8,1,1.2,1.4,1.6)$ alloys are summarized in Table 2 . It is worth noting that when the content of $\mathrm{Gd}$ is 1 at\% or above, in addition to the diffraction peaks of martensite phase, some additional peaks appears, as indicated by the arrows in Fig. 2. The intensity of the additional peaks increases slightly with increasing $\mathrm{Gd}$ content, implying that a new phase a formed. This suggests that the new phase may be the Gd-rich phase mentioned above. The crystal structure of the Gd-rich second phase needs to be investigated in further by TEM and XRD at different temperature.

The heating and cooling DSC curves for each alloy near the martensitic transformation temperature are presented in Fig. 3. It can be seen that an exothermic peak and an endothermic peak occur upon cooling and heating for the Ni-CoMn-In-Gd alloys. That is the typical characteristic of onestep thermoelastic martenstic transformation. Figure 4 shows the influence of $\mathrm{Gd}$ content on the martensite transformation temperature of $\mathrm{Ni}_{45} \mathrm{Co}_{5} \mathrm{Mn}_{35} \mathrm{In}_{15-\mathrm{x}} \mathrm{Gd}_{\mathrm{x}}$ alloys. When $\mathrm{x}=0$, the martensitic transformation start temperature $\left(\mathrm{M}_{\mathrm{s}}\right)$ is determined to be $286 \mathrm{~K}$. When the $\mathrm{Gd}$ content reaches 0.8 (at\%), the martensite transformation temperature decreases first, and then rises with the increase of Gd content. When the content of $\mathrm{Gd}$ is 1.6 at\%, the martensitic transformation start temperature is up to $394 \mathrm{~K}$ (about $108 \mathrm{~K}$ of $\mathrm{Ni}_{45} \mathrm{Co}_{5} \mathrm{Mn}_{35} \mathrm{In}_{13.4} \mathrm{Gd}_{1.6}$ ) and still has a tendency to increase. Based on our previous results, the martensitic trans-
Table 2 The lattice parameters and crystal phases $\mathrm{Ni}_{45} \mathrm{Co}_{5} \mathrm{Mn}_{35} \mathrm{In}_{15-\mathrm{x}} \mathrm{Gd}_{\mathrm{x}}$ alloys.

\begin{tabular}{cccccc}
\hline Composition & $\mathrm{a}(\AA)$ & $\mathrm{b}(\AA)$ & $\mathrm{c}(\AA)$ & $\beta\left(^{\circ}\right)$ & Crystal phase \\
\hline $\mathrm{Ni}_{45} \mathrm{Co}_{5} \mathrm{Mn}_{35} \mathrm{In}_{15}$ & 4.44 & 5.96 & 20.49 & 90.25 & $10 \mathrm{M}+\mathrm{A}$ \\
$\mathrm{Ni}_{45} \mathrm{Co}_{5} \mathrm{Mn}_{35} \mathrm{In}_{14.2} \mathrm{Gd}_{0.8}$ & 4.45 & 6.02 & 20.40 & 91.21 & $10 \mathrm{M}+\mathrm{A}$ \\
$\mathrm{Ni}_{45} \mathrm{Co}_{5} \mathrm{Mn}_{35} \mathrm{In}_{14} \mathrm{Gd}_{1}$ & 4.82 & 5.70 & 30.22 & 89.60 & $14 \mathrm{M}$ \\
$\mathrm{Ni}_{45} \mathrm{Co}_{5} \mathrm{Mn}_{35} \mathrm{In}_{13.8} \mathrm{Gd}_{1.2}$ & 4.31 & 5.96 & 30.16 & 93.90 & $14 \mathrm{M}$ \\
$\mathrm{Ni}_{45} \mathrm{Co}_{5} \mathrm{Mn}_{35} \mathrm{In}_{13.6} \mathrm{Gd}_{1.4}$ & 4.33 & 5.97 & 30.22 & 88.53 & $14 \mathrm{M}$ \\
$\mathrm{Ni}_{45} \mathrm{Co}_{5} \mathrm{Mn}_{35} \mathrm{In}_{13.4} \mathrm{Gd}_{1.6}$ & 4.26 & 6.74 & 30.06 & 90.72 & $14 \mathrm{M}$ \\
\hline
\end{tabular}

formation temperatures were increased by the substitution of $\mathrm{Gd}$ on $\mathrm{Ga}$ in Ni-Mn-Ga alloys. However, just when the content of $\mathrm{Gd}$ is up to 2 at\%, the $\mathrm{M}_{\mathrm{s}}$ of $\mathrm{Ni}_{50} \mathrm{Mn}_{29} \mathrm{Ga}_{19} \mathrm{Gd}_{2}$ alloy is raised to $390 \mathrm{~K}$, which is about $64 \mathrm{~K}$ of the ternary $\mathrm{Ni}_{50} \mathrm{Mn}_{29} \mathrm{Ga}_{21}$ alloy ${ }^{12}$. It indicates that the effect of increasing martensitic transformation temperature by the substitution of Gd for In in Ni-Co-Mn-In alloys is more obvious compared with the one of Ni-Mn-Ga-Gd alloy. The change of matrix composition is the main reason for the increase of martensite transition temperature. The EDS results from the Table 1 reveal that the content of $\mathrm{Ni}$ and $\mathrm{Co}$ in the matrix keeps almost unchanged and the content of $\mathrm{Mn}$ increases from 35.5 at $\%$ for $\mathrm{Ni}_{45} \mathrm{Co}_{5} \mathrm{Mn}_{35} \mathrm{In}_{15}$ alloy to 38.8 at\% for $\mathrm{Ni}_{45} \mathrm{Co}_{5} \mathrm{Mn}_{35} \mathrm{In}_{13.4} \mathrm{Gd}_{1.6}$ alloy. At the same time, the In content in the matrix decreases from 14.3 at $\%$ for $\mathrm{Ni}_{45} \mathrm{Co}_{5} \mathrm{Mn}_{35} \mathrm{In}_{15}$ alloy to 9.8 at $\%$ for $\mathrm{Ni}_{45} \mathrm{Co}_{5} \mathrm{Mn}_{35} \mathrm{In}_{13.4} \mathrm{Gd}_{1.6}$ alloy. The phase transformation temperatures rise with decrease of content of In in the matrix. This implies that the decrease of In content may be responsible for the increase in the martensitic transformation temperature. This agrees with the results obtained by Y. Feng et al. who showed that the martensitic transformation temperatures increased monotonically with the decrease of In content in $\mathrm{Ni}_{50} \mathrm{Mn}_{34} \mathrm{In}_{14} \mathrm{Fe}_{2}$ alloys ${ }^{13)}$. The reason for the decrease of martensitic transformation temperatures for the $\mathrm{Ni}_{45} \mathrm{Co}_{5} \mathrm{Mn}_{35} \mathrm{In}_{14.2} \mathrm{Gd}_{0.8}$ alloys needs to be further investigated in the future.

Figure 5 shows the temperature dependence of the magnetization $\mathrm{M}-\mathrm{T}$ for the $\mathrm{Ni}_{45} \mathrm{Co}_{5} \mathrm{Mn}_{35} \mathrm{In}_{14.2} \mathrm{Gd}_{0.8}$ alloy in the fields of $0.1 \mathrm{~T}$ and $5 \mathrm{~T}$. At a low magnetic field $(0.1 \mathrm{~T})$, as the temperature decreases, a sharp increase in magnetization is observed, corresponding to the paramagnetic magnetic transition of the austenite Curie temperature. The $\mathrm{T}_{\mathrm{c}}$, defined as the temperature where the $\mathrm{dM} / \mathrm{dT}$ is the minimum, as shown in the inset of Fig. 5(a), is $375 \mathrm{~K}$ for $\mathrm{Ni}_{45} \mathrm{Co}_{5} \mathrm{Mn}_{35} \mathrm{In}_{14.2} \mathrm{Gd}_{0.8}$ alloy. A further reduction in temperature results in a sudden drop in magnetization, which corresponds to martensitic transformation. During the heating process, the reverse martensitic transformation from martensite phase to austenite phase is confirmed by the magnetization jump. From Fig. 5(a), upon heating, reverse martensitic temperature starts at $\mathrm{A}_{\mathrm{s}}=257 \mathrm{~K}$ and ends at $\mathrm{A}_{\mathrm{f}}=$ $296 \mathrm{~K}$. Upon cooling, martensitic temperature starts at $\mathrm{M}_{\mathrm{s}}=$ $276 \mathrm{~K}$ and ends at $\mathrm{M}_{\mathrm{f}}=240 \mathrm{~K}$. From Fig. 5(b), the magnetic field of $5 \mathrm{~T}$ is applied at $150 \mathrm{~K}$, and the sample is heated to $380 \mathrm{~K}$, and then cooled to $150 \mathrm{~K}$. The curves measured at $5 \mathrm{~T}$ external magnetic field are slightly different from the curves at $0.1 \mathrm{~T}$ magnetic field, as shown in Fig. 5(b). It can 

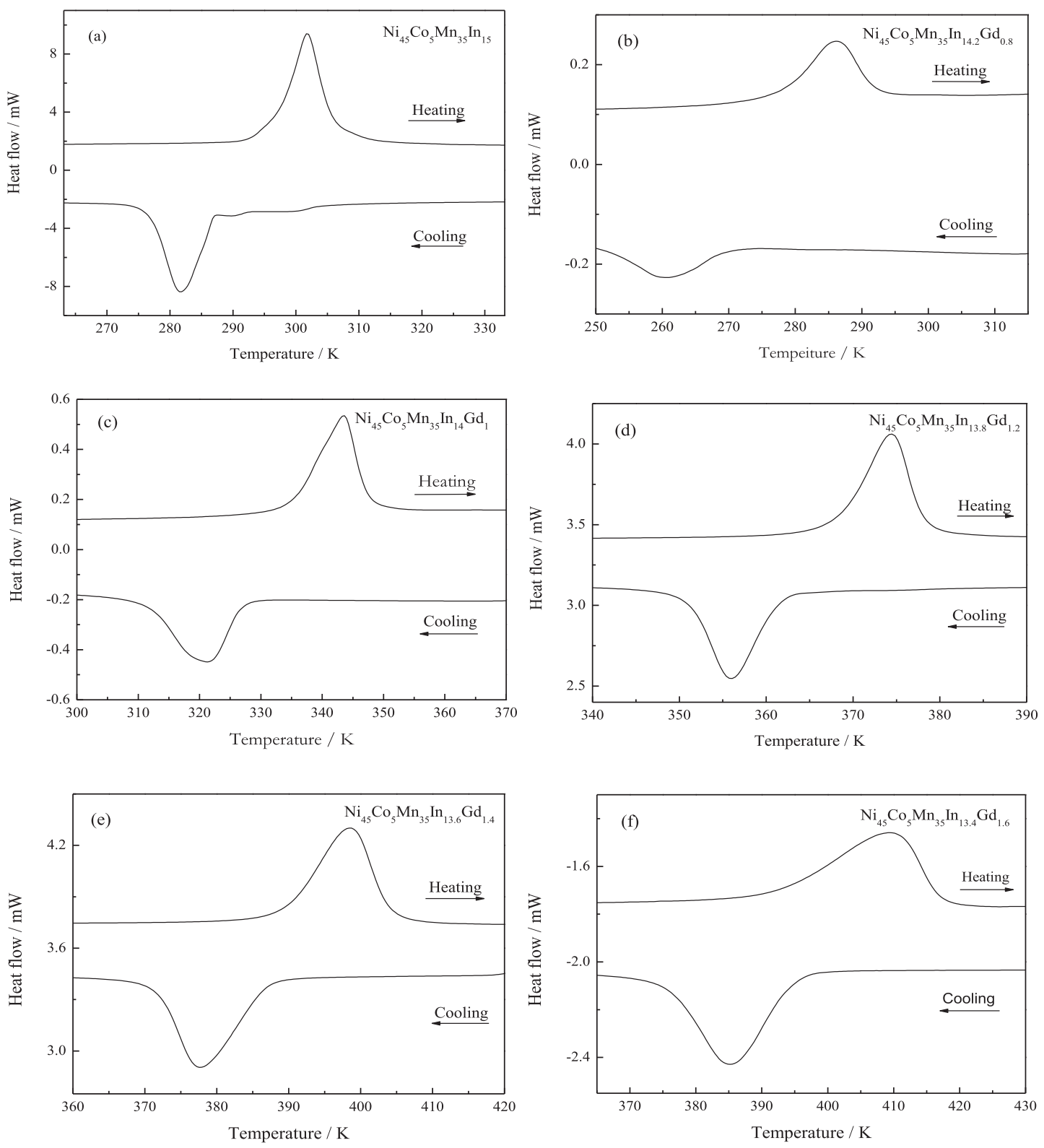

Fig. 3 DSC curves of $\mathrm{Ni}_{45} \mathrm{Co}_{5} \mathrm{Mn}_{35} \mathrm{In}_{15-\mathrm{x}} \mathrm{Gd}_{\mathrm{x}}(\mathrm{x}=0,0.8,1,1.2,1.4,1.6)$ alloys.

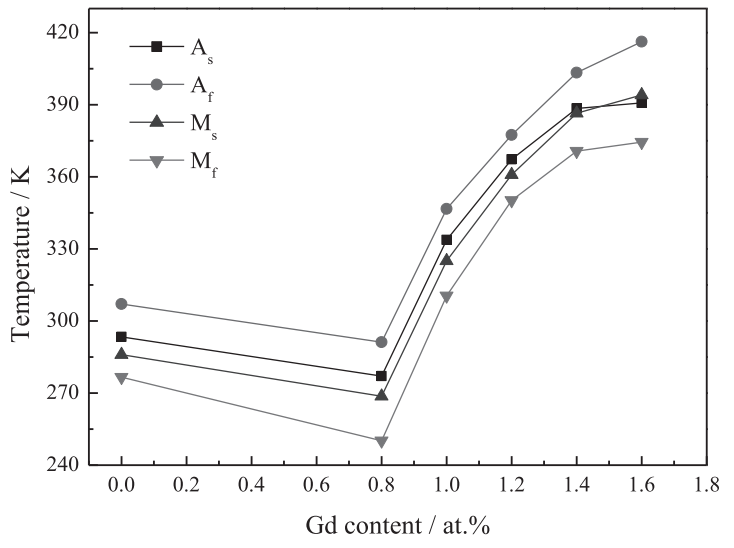

Fig. 4 The effect of Gd content on phase transformation temperatures of $\mathrm{Ni}_{45} \mathrm{Co}_{5} \mathrm{Mn}_{35} \mathrm{In}_{15-\mathrm{x}} \mathrm{Gd}_{\mathrm{x}}(\mathrm{x}=0,0.8,1,1.2,1.4,1.6)$ alloys. be seen that all the transition temperatures are reduced in the $5 \mathrm{~T}$ magnetic field compared to $0.1 \mathrm{~T}$. That indicates the magnetic-field-induced austenite transformation. The transformation hysteresis which is defined as $A_{f}-M_{s}$ are $20 \mathrm{~K}$ and $23 \mathrm{~K}$, respectively, at the applied fields of $0.1 \mathrm{~T}$ and $5 \mathrm{~T}$. The difference of magnetization between martensite and austenite is $0.8 \mathrm{emu} / \mathrm{g}$ at the field of $0.1 \mathrm{~T}$, but abruptly increases to about $87 \mathrm{emu} / \mathrm{g}$ with increasing magnetic field to $5 \mathrm{~T}$.

Isothermal magnetization curves $\mathrm{M}-\mathrm{H}$ for $\mathrm{Ni}_{45} \mathrm{Co}_{5} \mathrm{Mn}_{35} \mathrm{In}_{14.2} \mathrm{Gd}_{0.8}$ alloy are measured by $244 \mathrm{~K}$ to $292 \mathrm{~K}$, which is prepared by Fig. 6. At each temperature, the sample is magnetized from 0 to $5 \mathrm{~T}$, and then demagnetized from 5 to $0 \mathrm{~T}$. Temperature is increased by $3 \mathrm{~K}$ after the cycle is completed. The curves which are measured from $244 \mathrm{~K}$ to $289 \mathrm{~K}$ reveal that the magnetization of martensitic phase is lower than that of parent phase. The metamagnetic transition behavior which is observed in the sample indicates 

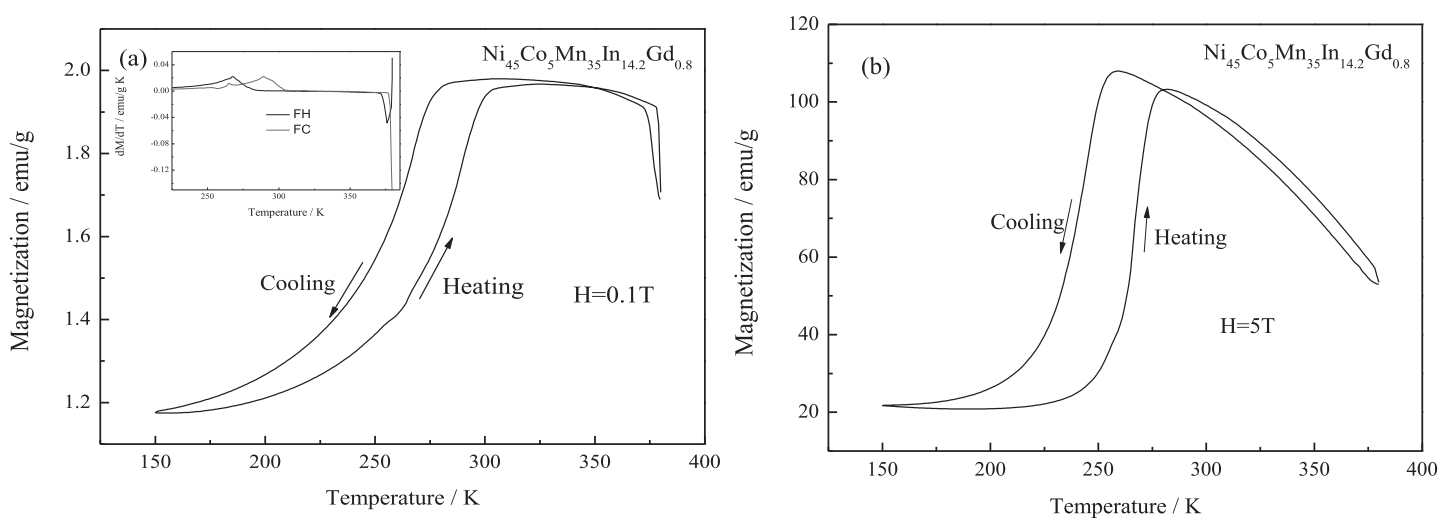

Fig. 5 Temperature dependence of magnetization in the $\mathrm{Ni}_{45} \mathrm{Co}_{5} \mathrm{Mn}_{35} \mathrm{In}_{14.2} \mathrm{Gd}_{0.8}$ alloy under magnetic fields $0.1 \mathrm{~T}$ and $5 \mathrm{~T}$.

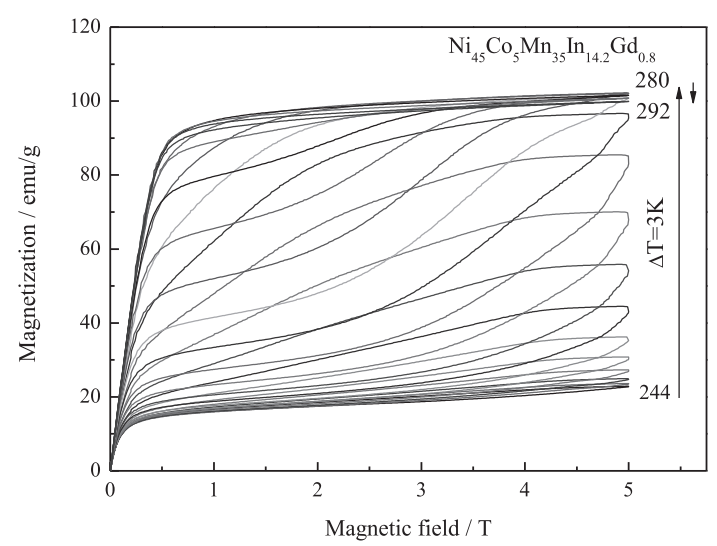

Fig. 6 Magnetization curves of the $\mathrm{Ni}_{45} \mathrm{Co}_{5} \mathrm{Mn}_{35} \mathrm{In}_{14.8} \mathrm{Gd}_{0.8}$ alloy at different temperatures.

the presence of magnetic field induces reverse martensitic transition (martensitic to austenite). At the temperature of $292 \mathrm{~K}$, the magnetization is saturated at a very low magnetic field, which indicates that the alloy is completely austenitized, where the M-H curves are reversible.

The magnetic entropy change $\left(\Delta \mathrm{S}_{\mathrm{M}}\right)$ is calculated based on the isothermal magnetization data by using the Maxwell relation:

$$
\Delta \mathrm{S}_{\mathrm{M}}=\int_{H_{I}}^{H_{F}}\left(\frac{\partial M(T, H)}{\partial T}\right)_{H} d H
$$

$\mathrm{H}_{\mathrm{I}}$ and $\mathrm{H}_{\mathrm{F}}$ are the initial and final magnetic field, respectively.

Figure 7 shows the magnetic entropy change as a function of temperature for $\mathrm{Ni}_{45} \mathrm{Co}_{5} \mathrm{Mn}_{35} \mathrm{In}_{14.2} \mathrm{Gd}_{0.8}$ alloy for various changes in the applied magnetic fields. At the field of $5 \mathrm{~T}$, the peak of $\Delta \mathrm{S}_{\mathrm{M}}$ appeals is $17.78 \mathrm{~J} / \mathrm{kg} \mathrm{K}$ at $277 \mathrm{~K}$. The magnetic entropy may be weakened by the Gd-rich phase. This agrees with the results obtained by J. Liu et al. who showed that the formation of the ferromagnetic $\gamma$ phase smears the martensitic transformation and dilutes the $\mathrm{MCE}^{14)}$.

The $\Delta \mathrm{S}_{\mathrm{M}}$ position shows a field dependence behavior, i.e. the peak $\Delta \mathrm{S}_{\mathrm{M}}$ shifts to a lower temperature with the increase of magnetic field. One possible reason for it may be related to the intersection of the $\mathrm{M}-\mathrm{H}$ curves around $\mathrm{A}_{\mathrm{s}}$. As shown in Fig. 6, the M-H curves of $286 \mathrm{~K}$ and $289 \mathrm{~K}$ intersect at 3.5 $\mathrm{T}$, below which the increase of magnetic field leads to a

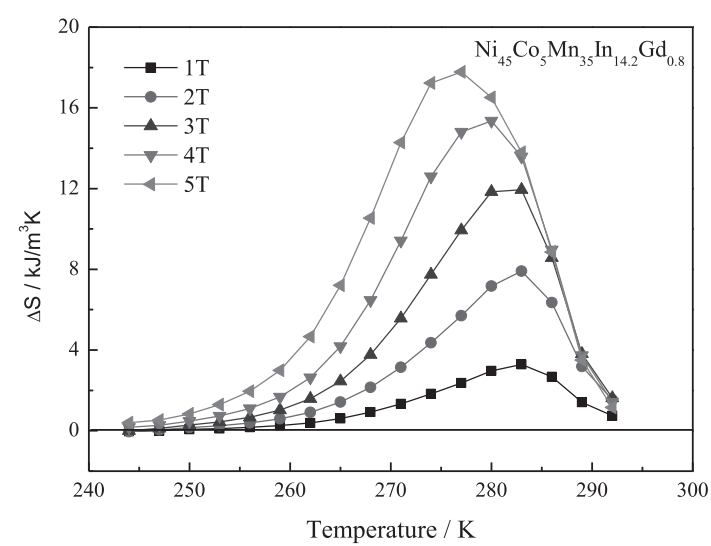

Fig. $7 \Delta \mathrm{S}_{\mathrm{M}}$ as a function of temperature of the $\mathrm{Ni}_{45} \mathrm{Co}_{5} \mathrm{Mn}_{35} \operatorname{In}_{14.2} \mathrm{Gd}_{0.8}$ alloy for various changes in applied magnetic field.

positive contribution to $\Delta \mathrm{S}_{\mathrm{M}}$. As a result, the maximum $\Delta \mathrm{S}_{\mathrm{M}}$ for a field change at the magnetic field of $5 \mathrm{~T}$ is only achieved at the lower temperature, i.e. $277 \mathrm{~K}$, where the adjacent M-H curves of $274 \mathrm{~K}$ and $280 \mathrm{~K}$ are not intersected. This agrees with the results obtained by J. Liu et al. who showed that the intersection of the $\mathrm{M}-\mathrm{H}$ curves around $\mathrm{A}_{\mathrm{s}}$ may be responsible for the shifts that peak $\Delta S_{M}$ is transferred to a lower temperature as the magnetic field changes $^{14)}$.

The isothermal $\mathrm{M}-\mathrm{H}$ curves are recorded up to $5 \mathrm{~T}$, as shown in Fig. 8. For the sample at the temperature of $223 \mathrm{~K}$ (far below $\mathrm{A}_{\mathrm{s}}$ ), the magnetic field up to $5 \mathrm{~T}$ almost cannot drive the phase transformation, so the field cycling has no influence on the M-H curve. The M-H curves at the temperature of $268 \mathrm{~K}$ ( $9 \mathrm{~K}$ below $\mathrm{A}_{\mathrm{s}}$ ), show that the first cycle can't coincide with the second one. This indicates that a large part of the field-induced austenite is trapped after the first cycle of the sample, which is consistent with the large thermal hysteresis in Fig. 8. It indicates that the magnetic field drives the inverse martensitic transformation. The M-H curves at $273 \mathrm{~K}$ ( $4 \mathrm{~K}$ below $\mathrm{A}_{\mathrm{s}}$ ) are similar with the M-H curves at $268 \mathrm{~K}$. At $323 \mathrm{~K}$ ( $46 \mathrm{~K}$ above $\mathrm{A}_{\mathrm{s}}$ ), the magnetization is saturated at a very low field, which indicates that the alloy is fully austenitized. This result well coincide with the martensite transformation temperature measured in M-T curves.

The useful parameter to assess the MCE is refrigerant capacity $\left(\mathrm{R}_{\mathrm{c}}\right)$, which is defined as: 


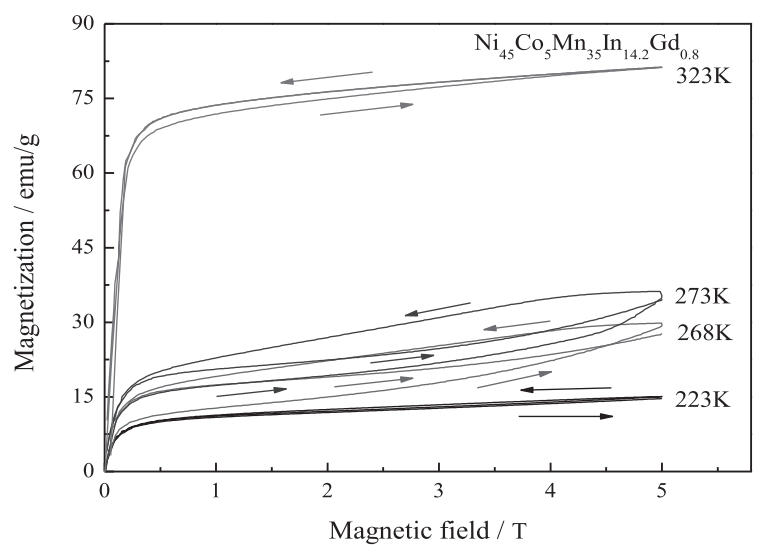

Fig. 8 Several cycles of isothermal M-H curves of $\mathrm{Ni}_{45} \mathrm{Co}_{5} \mathrm{Mn}_{35} \mathrm{In}_{14.2} \mathrm{Gd}_{0.8}$ alloy at different temperatures.

$$
\mathrm{R}_{\mathrm{c}}=\Delta \mathrm{S}_{\max } \delta \mathrm{T}_{\mathrm{FWHM}}
$$

Here, $\delta \mathrm{T}_{\mathrm{FWHM}}$ is the full width at half maximum of the $\Delta \mathrm{S}_{\mathrm{M}}(\mathrm{T})$ curve.

Although $\Delta \mathrm{S}_{\max }$ value of $\mathrm{Ni}_{45} \mathrm{Co}_{5} \mathrm{Mn}_{35} \mathrm{In}_{14.2} \mathrm{Gd}_{0.8}$ alloy is relatively small, $\Delta \mathrm{S}_{\mathrm{M}}(\mathrm{T})$ curves are distributed over a wide temperature. $\mathrm{R}_{\mathrm{c}}$ is about $356 \mathrm{~J} \mathrm{Kg}^{-1}$ at the field of $5 \mathrm{~T}$. This value is bigger than the $R_{c}$ of $334 \mathrm{~J} \mathrm{Kg}^{-1}$ of $\mathrm{Ni}_{42} \mathrm{Co}_{8} \mathrm{Mn}_{38} \mathrm{In}_{12}$ under $5 \mathrm{~T}^{15}$ ). The near-room-temperature MCE with a higher $R_{c}$ reveals the material system may be used in refrigeration application.

\section{Conclusion}

The effect of Gd addition on the microstructure, martensitic transformation and magnetic properties of $\mathrm{Ni}_{45} \mathrm{Co}_{5} \mathrm{Mn}_{35} \mathrm{In}_{15-\mathrm{x}} \mathrm{Gd}_{\mathrm{x}}$ alloys was studied. The results show that $\mathrm{Gd}$ doping has a clear refining effect on grain, and it forms a Gd-rich phase which contain $\mathrm{Ni}, \mathrm{Co}, \mathrm{Mn}$, In and $\mathrm{Gd}$. With the increase of $\mathrm{Gd}$ content, Gd-rich phase gradually becomes larger, and the trend is mainly distributed on grain boundary, some spread in the grains. $\mathrm{Ni}_{45} \mathrm{Co}_{5} \mathrm{Mn}_{35} \mathrm{In}_{15-\mathrm{x}} \mathrm{Gd}_{\mathrm{x}}$ alloys has a one-step thermoelastic martensitic transformation. The martensite transformation temperature decreases first, and then increases with the increase of Gd content. The martensitic transformation start temperature $\left(\mathrm{M}_{\mathrm{S}}\right)$ of $\mathrm{Ni}_{45} \mathrm{Co}_{5} \mathrm{Mn}_{35} \mathrm{In}_{13.4} \mathrm{Gd}_{1.6}$ alloy increases about $108 \mathrm{~K}$ compared with $\mathrm{Ni}_{45} \mathrm{Co}_{5} \mathrm{Mn}_{35} \mathrm{In}_{15}$ alloy. For $\mathrm{Ni}_{45} \mathrm{Co}_{5} \mathrm{Mn}_{35} \mathrm{In}_{14.2} \mathrm{Gd}_{0.8}$ alloy at $5 \mathrm{~T}$, the inverse magnetic entropy change $\left(\Delta \mathrm{S}_{\mathrm{M}}\right)$ reaches $17.78 \mathrm{~J} / \mathrm{kg} \mathrm{K}$ at $277 \mathrm{~K}$ and its $\mathrm{R}_{\mathrm{c}}$ is about $356 \mathrm{~J} \mathrm{Kg}^{-1}$. The larger magnetic entropy change near room temperature in the $\mathrm{Ni}_{45} \mathrm{Co}_{5} \mathrm{Mn}_{35} \mathrm{In}_{14.2} \mathrm{Gd}_{0.8}$ alloy is a promising working material for magnetic refrigeration.

\section{Acknowledgements}

This work is supported by National Natural Science Foundation of China (No. 51401122) and (No. 51671126).

\section{REFERENCES}

1) L. Mañosa, D. Gonzalezalonso, A. Planes, E. Bonnot, M. Barrio, J.L. Tamarit, S. Aksoy and M. Acet: Nat. Mater. 9 (2010) 478-481.

2) R. Kainuma, Y. Imano, W. Ito, Y. Sutou, H. Morito, S. Okamoto, O. Kitakami, K. Oikawa, A. Fujita, T. Kanomata and K. Ishida: Nature 439 (2006) 957-960.

3) H.E. Karaca, I. Karaman, B. Basaran, Y. Ren, Y.I. Chumlyakov and H.J. Maier: Adv. Funct. Mater. 19 (2009) 983-998.

4) T. Krenke, E. Duman, M. Acet, E.F. Wassermann, X. Moya, L. Manosa and A. Planes: Nat. Mater. 4 (2005) 450-454.

5) V.K. Sharma, M.K. Chattopadhyay, K.H.B. Shaeb, A. Chouhan and S.B. Roy: Appl. Phys. Lett. 89 (2006) 222509.

6) J. Liu, T. Gottschall, K.P. Skokov, J.D. Moore and O. Gutfleisch: Nat. Mater. 11 (2012) 620-626.

7) M.H. Phan and S.C. Yu: J. Magn. Magn. Mater. 308 (2007) 325-340.

8) L. Pareti, M. Solzi, F. Albertini and A. Paoluzi: Eur. Phys. J. B 32 (2003) 303-307.

9) B. Hernando, J.L.S. Llamazares, J.D. Santos, V.M. Prida, D. Baldomir, D. Serantes, R. Varga and J. González: Appl. Phys. Lett. 92 (2008) 132507.

10) K. Oikawa, W. Ito, Y. Imano, Y. Sutou, R. Kainuma, K. Ishida, S. Okamoto, O. Kitakami and T. Kanomata: Appl. Phys. Lett. 88 (2006) 122507.

11) K. Tsuchiya, A. Tsutsumi, H. Ohtsuka and M. Umemoto: Mater. Sci. Eng. 378 (2004) 370-376.

12) L. Gao, X. Shen and J. Xu: Mater. Trans. 56 (2015) 1186-1191.

13) Y. Feng, J.H. Sui, H.B. Wang and W. Cai: J. Magn. Magn. Mater. 324 (2012) 1982-1984.

14) J. Liu, T.G. Woodcock, N. Scheerbaum and O. Gutfleisch: Acta Mater. 57 (2009) 4911-4920.

15) F. Chen, Y.X. Tong, L. Li, L. Sanchez Llamazares, C.F. SanchezValdes and P. Muller: J. Alloy. Compd. 725 (2017) 603-609. 